\title{
Effects of a prevention program on multiple health- compromising behaviours in adolescence: a cluster randomized controlled trial
}

\section{Authors}

Elias Allara (1,2), Paola Angelini (3), Giuseppe Gorini (4), Sandra Bosi (5), Giulia Carreras (4), Cristina Gozzi (5), Andrea Martini (4), Marco Tamelli (5), Ranadhir Reddy Punreddy (1), Fabrizio Faggiano (1)

(1) Department of Translational Medicine, Università del Piemonte Orientale, Novara, Italy

(2) Department of Public Health and Primary Care, University of Cambridge, Cambridge, United Kingdom

(3) Public Health Unit, Emilia-Romagna Regional Authority, Bologna, Italy

(4) Environmental and Occupational Epidemiology Unit, Cancer Prevention and Research Institute (ISPO), Florence, Italy

(5) Italian League against Cancer (LILT), Reggio Emilia, Italy

\section{Corresponding author}

Elias Allara

elias.allara@med.uniupo.it

Department of Translational Medicine

Università del Piemonte Orientale

Via Solaroli 17

28100 Novara

Italy

Word count (background to conclusions): 3493

Word count (abstract): 250

Last updated: $27^{\text {th }}$ February 2019 


\section{Abstract}

We aimed to assess the effectiveness of 'Paesaggi di Prevenzione', a school-based prevention program delivered by trained teachers and designed to tackle smoking, alcohol misuse, dietary risks, and physical inactivity in adolescence.

We evaluated the program between 2010-2013 with a two-arm, parallel-group, multicentre cluster randomized controlled trial in which schools were the units of randomization. We collected data on healthcompromising behaviours using self-reported measurements of behaviour frequency administered before and after program implementation. We used multivariable mixed-effects logistic regression models to estimate program effects on health-compromising behaviours.

The analysis sample included 3,410 middle school students and 1,651 high school students. Among middle school students, mean age at baseline was 12 years (standard deviation [SD] 0.5 years), 51\% were boys, and $41 \%$ had high socioeconomic status [SES] (defined as having at least one parent/guardian with university level education). In high school students, mean age at baseline was 14 years (SD 0.7 years), 56\% were boys, and 31\% had high SES. The program did not have effects on smoking, alcohol misuse, and physical activity. The program had iatrogenic effects in regard to some eating behaviours, resulting in (i) lower odds of fruit consumption among middle-school students (odds ratio [OR] 0.82; 95\% confidence interval [CI] 0.68-0.99) and (ii) lower odds of having breakfast every day in high-school students at the post-intervention measurement (OR 0.76; 95\% $\mathrm{Cl} 0.58-0.99$ ) but not at one-year follow-up (OR 0.94; 95\% $\mathrm{Cl} 0.69-1.28$ ). Due to the possibility of unintended effects, we advise against disseminating 'Paesaggi di Prevenzione' in its present form.

\section{Trial registration}

ISRCTN00953701

\section{Keywords}

School-based prevention; Tobacco; Alcohol; Dietary risks; Eating behaviour; Physical activity; Cluster randomized controlled trial; Youth; Adolescence; Evidence-based prevention; Multiple imputation 


\section{Background}

Twelve percent of Italian children aged 11-15 years old have smoked at least once in their life, and this proportion ranges from $1 \%$ among 11 -year-olds to $29 \%$ among 15 -year-olds (Cavallo et al., 2016). Around $57 \%$ of them have drunk alcohol at least once, ranging from $36 \%$ among 11 -year-olds to $80 \%$ among 15 -year-olds. By contrast, only $17 \%$ ate fruit, $11 \%$ ate vegetables more than once a day, and only $11 \%$ achieved the WHO-recommended 60 minutes of daily physical activity (WHO, 2010). In adolescence, engaging in risky behaviour and avoiding healthful behaviour increases not only the risk of short-term effects on physical and psychological health (Elders et al., 1994; Marshall, 2014; Strauss, 2000; Swallen et al., 2005), but has also been associated with deleterious health effects in adult life (Biro and Wien, 2010; Elders et al., 1994; Freedman et al., 2005; McCambridge et al., 2011). For this reason, a number of international initiatives have highlighted the value of preventing health-compromising behaviours and thus reduce the burden of disability and mortality. The European 'Gaining Health' strategy (WHO Europe, 2006) produced a political response in Italy (DPCM 4 Maggio, 2007) which set the objective of reducing four health-compromising behaviours at a national level: smoking, alcohol misuse, dietary risks, and physical inactivity. The Regional Authority of Emilia-Romagna, a large administrative area in Northern Italy (population in 2017: 4.4 million (Italian National Institute of Statistics (ISTAT), 2017)), has been particularly active in fostering actions to meet the national objective. These included the development of a successful program to prevent smoking in adolescence (Bosi et al., 2013; Gorini et al., 2014), and 'Paesaggi di Prevenzione', an ambitious multi-component school-based program aimed at preventing all of the four healthcompromising behaviours addressed by the 'Gaining Health' prevention strategy in Italy (Allara et al., 2015).

It is well established that some risk behaviours such as alcohol misuse, tobacco smoking, dietary risks and physical inactivity cluster in adolescence, both at a group level and at an individual level (Basen-Engquist et al., 1996; Dumith et al., 2012; Farhat et al., 2010; MacArthur et al., 2012; Nunes et al., 2016; Silva et al., 2012; WHO Europe, 2006), and are associated with increased and cumulative risk of poor educational attainment, morbidity and premature mortality (Khaw et al., 2008; Kvaavik et al., 2010). When 'Paesaggi di Prevenzione' was devised, the approach of targeting 
some of these risk behaviours simultaneously appeared particularly attractive in terms of efficiency. Although some programs had targeted multiple risk behaviours (Faggiano et al., 2008; Noar and Zimmerman, 2005), no universal program had aimed to simultaneously prevent all of the four health-compromising behaviours targeted by the 'Gaining Health' strategy in Italy. In this study, we aimed to assess the effectiveness of 'Paesaggi di Prevenzione' in reducing smoking, alcohol misuse, dietary risks, and physical inactivity.

\section{Methods}

\section{The 'Paesaggi di Prevenzione' program}

Detailed information about the 'Paesaggi di Prevenzione' program is available elsewhere (Allara et al., 2015; Angelini et al., 2013). Briefly, ‘Paesaggi di Prevenzione’ is a universal, multi-component prevention program aiming to develop life skills in 12 to 14 years old students and reduce initiation to tobacco smoking and alcohol misuse, dietary risks, and physical inactivity. The program is based on two components, a classroom component and a school policy. The classroom component comprises a 4-track interactive classroom curriculum, one for each behaviour targeted, delivered by trained teachers with the support of audio-visual media. Teachers can choose the pathways to implement, tailoring the program to the specific needs of their students. Interactive classroom activities aim to enhance decision making skills, problem solving, personal and interpersonal skills, stress and emotion management, and effective communication. Teacher training follows a train-thetrainer model. In this evaluation study, 80 public health professionals and lead teachers (who were trained over two 8-hour sessions administered centrally at the Health Promotion centre of the Italian League against Cancer [LILT] in Reggio Emilia, Italy) trained 271 teachers over three 4-hour sessions.

The second component of the program consists in the development of a school policy involving students, teachers and families, which is approved by school authorities (Allara et al., 2015). School policy comprises smoking bans for both student and teachers inside and outside school facilities, prohibition to use alcohol during school events, promotion of use of healthy foods in selling 
machines and canteens, walking activities involving families and local communities, and team games.

Program manuals and materials can be requested on www.luoghidiprevenzione.it/PaesaggiDiPrevenzione/default.aspx.

\section{Study design}

We evaluated the effectiveness of 'Paesaggi di Prevenzione' with a two-arm, parallel-group, multicentre cluster randomized controlled trial in which schools were the units of randomization and students were the units of analysis. We followed CONSORT guidelines for randomized controlled trials (Schulz et al., 2010). Further details on the study design are available herein and in a previous publication (Allara et al., 2015).

Trial registration. We registered the study prospectively on www.controlled-trials.com with number ISRCTN00953701.

Enrollment and sample size. We enrolled state middle schools from all urban administrative areas of the Emilia-Romagna region in Italy, and state high schools from all urban administrative areas except those based in Reggio Emilia as they were already involved in another trial (Bosi et al., 2013; Gorini et al., 2014). We anticipated the sample size separately for middle and high school students, based on the health-compromising behaviour anticipated to have the lowest baseline prevalence, i.e. tobacco smoking (Allara et al., 2015). We estimated that a baseline sample of 5200 middle school and 3400 high school students would have been needed to detect a $30 \%$ reduction in past30 -day smoking prevalence in the intervention group, while assuming $80 \%$ power, $5 \%$ probability of type I error, and 0.039 intraclass correlation coefficient.

School selection, randomization and allocation concealment. From all schools that expressed their interest in the trial, we extracted a random sample meeting the requirements of power estimation. We stratified the schools included in the trial by socioeconomic status (SES), number of students, 
type (high vs. middle school) to form balanced strata, each comprising two schools. We matched high schools also by subtype, i.e. vocational or preparatory. Within each stratum, we randomly allocated schools to the experimental or control group using a computer-generated list of random numbers. An independent contractor, Università del Piemonte Orientale conducted the allocation procedure centrally.

Process evaluation. We collected information regarding number and type of program track implemented from teachers for each class in the intervention group.

Study groups. Students in the intervention group received the 'Paesaggi di Prevenzione' program from January 2011 to April 2012. Students in the control group received the standard school curriculum over the same period and were not exposed to other structured prevention programs. Only teachers of the intervention group $(n=271)$ followed the training. All classes in the intervention group were exposed to the school policy components while only a subset was exposed to all behaviour-specific tracks.

Measurements. Students from both study groups completed a questionnaire prior to program administration, between October and December 2010, and a post-intervention questionnaire in May 2012. High school students also filled out a third questionnaire in May 2013. Further information about the measures used in this study is available in Appendix A.

\section{Ethics}

The Ethics Committee of the Local Health Authority of Reggio Emilia, Italy approved the study (Allara et al., 2015). Students, parents and guardians were informed about the purpose and methodology of the trial, and students had the option to opt out at any moment. Questionnaires were anonymous and we performed linkage between pre- and post-intervention questionnaires using anonymous 9character identification codes generated by the students. This approach was validated (Galanti et al., 2007) and used successfully in previous research (Faggiano et al., 2008; Gorini et al., 2014). 


\section{Outcomes.}

We assessed program effects on 4 health-related behaviours reflected by 14 outcomes. In line with similar studies focusing on adolescent health behaviour (Angelini et al., 2010; Currie et al., 2008; Faggiano et al., 2007; Sloboda et al., 2009b), we selected the following outcomes: (i) past-30-day cigarette smoking and alcohol misuse, (ii) relevant eating behaviours such as fruit and vegetables consumption, breakfast frequency, drinking of sugar-sweetened beverages, eating of crisps, snacks, cakes, and ice creams; (iii) frequency of moderate or vigorous physical activity, the latter defined as 'any activity that results in increased heart rate and breathlessness some of the time for at least 60 minutes' (Adams et al., 2013); (iv) frequency of sedentary behaviour such as watching television and using computers or videogames (Currie et al., 2008). Further information about the measures from which these outcomes originate is available in Appendix $\mathbf{A}$.

\section{Statistical analysis}

We analysed middle and high school students separately and in their original assigned group, regardless of the dosage of intervention received, and in line with the intention-to-treat approach. Owing to the high proportion of missing data observed for some outcomes, we complemented this using multiple imputation (Ian R. White et al., 2011).

We checked the distribution of baseline sociodemographic variables and health behaviours in the two study groups with crosstabulations as described previously (Allara et al., 2015). We carried out similar descriptive analyses to evaluate the distribution of post-intervention health behaviours. To account

for intra-school clustering, we fitted mixed effects logistic regression models assuming that the log odds of health behaviour varied randomly between schools. For each health behaviour assessed at post intervention, we built a separate regression model adding a random intercept for each school, a fixed binary effect for the intervention ( 1 = intervention group; $0=$ control group), and the following potential confounders: a fixed binary effect for the behaviour at baseline, continuous age, gender, socioeconomic status (SES), and parent origin (Kahan et al., 2014; Roberts and Torgerson, 1999). We used parent educational level as a proxy for SES, in line with previous research (Gorini et al., 2014): 
low SES indicated that both parents or guardians had either an elementary school or a middle school diploma; average SES meant that at least one parent or guardian had a high school diploma; high SES indicated that at least one parent or guardian had a university degree. We recoded parent origin as a binary variabile: at least one parent of Italian origin vs. both parents of non-Italian descent. For high school students, the regression model included an additional parameter indicating if the student was attending a vocational or a university-preparatory school.

The proportion of missing data in the outcomes ranged from $<1 \%$ to $7 \%$ for middle schools and from $<1 \%$ to $45 \%$ for high schools $(<1 \%$ to $21 \%$ when considering only baseline and post-intervention measurements). While the proportion of missing data was similar if not lower compared to other prevention trials (Bell et al., 2014; Nanchahal et al., 2012), exclusion of participants with missing data is inefficient and can lead to bias if participants excluded from analysis differ in some respect from those who are included. Furthermore, although the pattern of missingness in this study was dominated by attrition, we observed some baseline and intermediate missing outcomes. We therefore imputed missing data using a multiple imputation with chained equations approach that does not require a particular pattern of missingness and allows imputing the outcome of interest simultaneously for all measurements (Nanchahal et al., 2012; Royston, 2004; Ian R White et al., 2011). For each outcome variable, we fitted 7 joint imputation models. Each imputation model included one of the following variables as the response variable and all the others as predictors of missingness: outcome at baseline, outcome at post-intervention, outcome at 1-year follow-up (only for high schools), age, gender, SES, parent origin. Each imputation model also included two nonmissing predictors of missingness: school identifier and (only for high school students) a binary parameter indicating vocational vs university-preparatory school. We allowed 200 imputation datasets per outcome and conducted analyses separately for the intervention and control groups and for middle and high schools. We fitted mixed-effects regression models within each imputation dataset and then calculated their pooled estimate as per Rubin's rule (Rubin, 1976). As sensitivity analysis, we repeated all analyses using only complete cases. We conducted all analyses using Stata/MP 13.0. 


\section{Results}

\section{Trial profile}

Figure 1 summarizes the trial profile. The study included 44 middle schools and 34 high schools equally allocated to two study arms. At baseline, mean age of middle school students was 12 years (standard deviation [SD] 0.5 years), 51\% were boys, and $41 \%$ had high socioeconomic status [SES], defined as having at least one parent/guardian with university-level education. In high schools, mean age at baseline was 14 years (SD 0.7 years), 56\% were boys, and 31\% had high SES. Further information about baseline characteristics is available in a separate paper (Allara et al., 2015).

Among middle school students, 2384 students in the intervention group and 2316 in the control group received the pre-intervention questionnaire. After merging questionnaires collected before and after the intervention, we analysed 1827 students in the intervention group and 1583 students in the control group. Among high school students, 1389 students in the intervention group and 1563 in the control group received the pre-intervention questionnaire. After matching the questionnaires of students who were present at baseline and at least one post-intervention measurement (thereby excluding those present only at baseline), the analysis sample included: at baseline, 755 participants in the intervention arm and 896 in the control arm; in the post-intervention measurement, respectively 718 and 729 ; at one year of follow-up, 440 and 558.

\section{Program implementation}

Among schools randomized to the intervention arm, all 109 middle school classes and 56 of the 63 high school classes (89\%) implemented at least one of the program's four tracks (a minority of high school classed could not implement any tracks due to teachers' competing teaching commitments). No classes from middle schools and one class from high schools implemented all tracks. In middle schools, $92 \%$ of classes were administered the diet-related track, 39\% the smoking prevention track, $25 \%$ the physical activity track, and 9\% the alcohol prevention track. In high schools, around 51\% of classes implemented the alcohol prevention track, 46\% the smoking prevention track, $40 \%$ the diet- 
related track, and $22 \%$ the physical activity track. All classes in the intervention group were exposed to the school policy component.

\section{Program effectiveness}

This section presents associations estimated after multiple imputation of missing data. These findings are consistent with the corresponding estimates from complete-case analysis (Appendix B).

\section{Tobacco smoking and alcohol misuse}

The program did not produce effects on smoking (Table 1) and alcohol-related behaviour (Table 2) among middle and high school students, although we observed a small, non-significant protective effect in regard to frequent alcohol misuse in middle school students.

\section{Eating behaviour}

Middle schools. The program decreased daily consumption of fruit (odds ratio [OR] 0.82; 95\% confidence interval $[\mathrm{Cl}]$ 0.68-0.99) after multiple imputation and while adjusting for fruit consupmtion at baseline, age, sex, SES, and parent origin (Table 3A).

High schools. In the post-intervention measurement (Table 3B), the program reduced the odds of having breakfast every day $(\mathrm{OR} 0.76 ; 95 \% \mathrm{Cl} 0.58-0.99)$ after multiple imputation in the adjusted model. This effect disappeared at the one-year follow-up measurement (OR 0.94; 95\% $\mathrm{Cl} 0.69-1.28$ ).

\section{Physical activity and sedentary behaviour}

There is no evidence of program effects regarding physical activity and sedentary lifestyle of middle and high school students (Table 4).

\section{Discussion}

This multicentre randomized controlled trial is the largest carried out in Italy to evaluate a behavioural prevention program. Furthermore, this trial assesses the first prevention program aiming to simultaneously tackle four risk behaviours in adolescence. However, its findings are disappointing. 
The program did not elicit behavioural changes in regard to smoking, alcohol misuse and physical activity, and reduced consumption of fruit and vegetables among middle school students.

At the time of writing and to the best of our knowledge, no other study has evaluated interventions aimed at simultaneously preventing the four health-compromising behaviours evaluated in this trial. However, it is possible to compare the effects of this study with those of the studies that have evaluated these behaviours separately. The literature supports the effectiveness of some interventions that aim to prevent alcohol misuse (Allara et al., 2016; Faggiano et al., 2010; Foxcroft and Tsertsvadze, 2011), poor eating behaviour (Waters et al., 2011) and insufficient physical activity (Waters et al., 2011) among adolescents. There is limited agreement on the effectiveness of smoking interventions for smoking prevention (Thomas et al., 2013) although some studies have shown promise (Faggiano et al., 2010; Gorini et al., 2014).

It is possible that the complexity of addressing simultaneously four risk behaviours may have been a hindrance to implementation fidelity and therefore partly responsible for the unintended effects on diet and physical activity. 'Paesaggi di Prevenzione' was designed to promote the empowerment of students through an exploration of their own needs and desires, in order to increase self-awareness, self-efficacy and self-determination (Allara et al., 2015; Angelini et al., 2013; Bosi, 2012; Bosi et al., 2013; Botvin and Griffin, 2004). The program was also devised to actively engage the students, their families and teachers, and in turn elicit shared decisions to change the environment around the students. Such a change would produce school policies embedded in a school manifesto summarizing the vision of each school on health-compromising behaviours and the actions that would follow. The effects of school policies on lifestyle have been evaluated by a growing number of studies (Coppo et al., 2014), and a large trial has shown favourable findings on smoking in adolescence (Gorini et al., 2014). However, in order to ensure that all phases are conducted efficiently and effectively, it is necessary that all tasks are properly manualized and monitored (Sloboda et al., 2009a). While the manualization of components on alcohol and smoking was well defined in 'Paesaggi di Prevenzione', information on the delivery of the diet and physical activity components was more concise. Furthermore, it has been noted that most teachers who had previous experience promoting healthful diet and physical activity, used to do so by focusing on knowledge rather than life skills. Together, lack of detailed manualization and excessive focus on knowledge components may have contributed to a 
greater variability in program implementation, causing part of the iatrogenic effects on these behaviours.

This trial has some limitations. Firstly, there is a considerable proportion of missing data. This is in line with other prevention studies (Bell et al., 2014; Nanchahal et al., 2012) and has been explicitly addressed at the analysis stage using multiple imputation methods. It is worth noting that multiple imputation can provide unbiased estimates when the data is missing at random, i.e. when - given the observed data-the missingness mechanism does not depend on unobserved data. Owing to ethical concerns and anonymization procedures, our dataset could not capture some potential predictors of missingness such as individual school absenteeism and performance. However, in our imputation models we accounted for all predictors of missingness available in our dataset, including SES, origin, and (for high school students) attendance at vocational school-all factors that are associated to school absenteinsm and performance (Banerjee, 2016; Goldstein et al., 2003). Secondly, it was possible to administer only one post-intervention questionnaire to middle school students, limiting the amount of information that could be captured. Middle school lasts three years in Italy, and this renders longer follow-up expensive as it requires individual tracking of each student as they progress to high school. Owing to resource constraints, this solution was not practicable. Thirdly, the modular structure of the program enabled teacher to tailor the program to the needs of their class, which may have diluted program effects on some behaviours. However, the intention to treat effects presented in this paper generally overlap with additional analyses that we performed to estimate the effect of specific tracks of the program on their target behaviour (for example, the effects of the alcohol prevention track on alcohol use). This suggests that the modular structure of the program is unlikely to have had a substantial impact on the program results. These effects may instead be related to how the program was manualized and delivered.

It is worth noting that the 'Paesaggi di Prevenzione' trial is one of the few conducted in Italy for the evaluation of a prevention intervention. Only a minority of prevention interventions are evaluated in Italy (Coffano, 2009), and even fewer are evaluated by appropriate studies (Faggiano et al., 2014). This is partly due to the perception that a rigorous evaluation necessarily requires considerable resources. This perception has an impact on both research and practice, hindering the advancement of prevention science and the supply of effective programs. This study shows that it is possible to 
conduct a large and rigorous study without specific funds, if health professionals and the institutions to which they belong are engaged from the beginning and feel committed to the project, under the scientific coordination of academic research centres.

Overall, due to the presence of possible iatrogenic effects, 'Paesaggi di Prevenzione' does not appear suitable to be disseminated in its present form. The results of this study confirm that prevention programs based on the best theoretical approaches may be ineffective, and highlight the importance of evaluating all novel prevention interventions. 


\section{List of abbreviations}

$\mathrm{Cl}$ : confidence interval

OR: odds ratio

SES: socioeconomic status

SD: standard deviation

\section{Acknowledgements}

We thank the Italian League against Cancer (LILT) of Reggio Emilia (Italy) for supporting the evaluation of the 'Paesaggi di Prevenzione' program. We are grateful to the students who participated to this study, the Regional Health Authority of Emilia-Romagna for their strong commitment and support, the teachers involved in the program, and the school authorities.

\section{Competing interests}

The authors declare that there are no conflicts of interest. 


\section{References}

Adams, M.A., Johnson, W.D., Tudor-Locke, C., 2013. Steps/day translation of the moderate-tovigorous physical activity guideline for children and adolescents. Int. J. Behav. Nutr. Phys. Act. 10, 49. https://doi.org/10.1186/1479-5868-10-49

Allara, E., Angelini, P., Gorini, G., Bosi, S., Carreras, G., Gozzi, C., Martini, A., Tamelli, M., Storani, S., Faggiano, F., 2015. A prevention program for multiple health-compromising behaviors in adolescence: Baseline results from a cluster randomized controlled trial. Prev. Med. (Baltim). 71, 20-26. https://doi.org/10.1016/j.ypmed.2014.12.002

Allara, E., Beccaria, F., Molinar, R., Marinaro, L., Ermacora, A., Coppo, A., Faggiano, F., Diario della Salute Evaluation Support Team, 2018. A School-Based Program to Promote Well-Being in Preadolescents: Results From a Cluster Quasi-Experimental Controlled Study. J. Prim. Prev. https://doi.org/10.1007/s10935-018-0530-y

Allara, E., Ferri, M., Faggiano, F., 2016. National Preventive Approaches to Tackle Alcohol Misuse, in: The SAGE Handbook of Drug and Alcohol Studies. SAGE Publications Ltd, 1 Oliver's Yard, 55 City Road London EC1Y 1SP, pp. 192-211. https://doi.org/10.4135/9781473921986.n12

Angelini, P., Baldacchini, F., Mignani, R., 2010. Stili di vita e salute dei giovani in età scolare. Rapporto sui dati regionali HBSC 2009-2010 Regione Emilia-Romagna.

Angelini, P., Faggiano, F., Bosi, S., Gorini, G., Beltrami, P., Tamelli, M., Monti, C., Allara, E., Carreras, G., Martini, A., Storani, S., Fridel, M., Finarelli, A.C., il Gruppo regionale "Paesaggi di prevenzione", Gruppo regionale "Paesaggi di Prevenzione," 2013. Contrastare i principali fattori di rischio in adolescenza: il programma "Paesaggi di Prevenzione" e la sua valutazione tramite uno studio controllato e randomizzato [WWW Document]. URL http://www.luoghidiprevenzione.it/_Public/Files/Pagine_PaesaggiDiPrevenzione/2013-0222_PdP_report_baseline.pdf

Banerjee, P.A., 2016. A systematic review of factors linked to poor academic performance of disadvantaged students in science and maths in schools. Cogent Educ. 3. https://doi.org/10.1080/2331186X.2016.1178441

Basen-Engquist, K., Edmundson, E.W., Parcel, G.S., 1996. Structure of health risk behavior among high school students. J. Consult. Clin. Psychol. 64, 764-775. https://doi.org/10.1037/0022006X.64.4.764

Bell, M.L., Fiero, M., Horton, N.J., Hsu, C.-H., 2014. Handling missing data in RCTs; a review of the top medical journals. BMC Med. Res. Methodol. 14, 118. https://doi.org/10.1186/1471-228814-118

Biro, F.M., Wien, M., 2010. Childhood obesity and adult morbidities. Am. J. Clin. Nutr. 91, 1499S1505S. https://doi.org/10.3945/ajcn.2010.28701B

Bosi, S., 2012. I Paesaggi della Prevenzione - Guida per promotori della salute. Giunti Progetti Educativi.

Bosi, S., Gorini, G., Tamelli, M., Monti, C., Storani, S., Carreras, G., Martini, A., Allara, E., Angelini, P., Faggiano, F., 2013. A school-based peer-led smoking prevention intervention with 
extracurricular activities: the LILT-LdP cluster randomized controlled trial design and study population. Tumori 99, 572-7. https://doi.org/10.1700/1377.15304

Botvin, G.J., Griffin, K.W., 2004. Life Skills Training: Empirical Findings and Future Directions. J. Prim. Prev. 25, 211-232. https://doi.org/10.1023/B:JOPP.0000042391.58573.5b

Cavallo, F., Lemma, P., Dalmasso, P., Vieno, A., Lazzeri, G., Galeone, D., 2016. $4^{\circ}$ rapporto sui dati HBSC Italia 2014. Torino.

Coffano, E., 2009. Guadagnare salute in adolescenza: ricognizione delle esperienze di prevenzione e promozione della salute in Italia.

Coppo, A., Galanti, R.M., Buscemi, D., Giordano, L., Faggiano, F., 2014. School policies for preventing smoking among young people. Cochrane Database Syst. Rev.

https://doi.org/10.1002/14651858.CD009990.pub2

Currie, C., Gabhainn, S.N., Godeau, E., Roberts, C., Smith, R., Currie, D., Picket, W., Richter, M., Morgan, A., Barnekow, V., 2008. Inequalities in young people's health. HBSC international report from the 2005/2006 survey.

DPCM 4 Maggio, 2007. Documento programmatico “Guadagnare salute.” Presidenza del Consiglio dei Ministri.

Dumith, S.C., Muniz, L.C., Tassitano, R.M., Hallal, P.C., Menezes, A.M.B., 2012. Clustering of risk factors for chronic diseases among adolescents from Southern Brazil. Prev. Med. (Baltim). 54, 393-6. https://doi.org/10.1016/j.ypmed.2012.03.014

Elders, M.J., Perry, C.L., Eriksen, M.P., Giovino, G.A., 1994. The report of the Surgeon General: preventing tobacco use among young people. Am. J. Public Health 84, 543-7.

Faggiano, F., Allara, E., Giannotta, F., Molinar, R., Sumnall, H., Wiers, R., Michie, S., Collins, L., Conrod, P., 2014. Europe needs a central, transparent, and evidence-based approval process for behavioural prevention interventions. PLoS Med. 11, e1001740.

https://doi.org/10.1371/journal.pmed.1001740

Faggiano, F., Galanti, M.R., Bohrn, K., Burkhart, G., Vigna-Taglianti, F., Cuomo, L., Fabiani, L., Panella, M., Perez, T., Siliquini, R., van der Kreeft, P., Vassara, M., Wiborg, G., 2008. The effectiveness of a school-based substance abuse prevention program: EU-Dap cluster randomised controlled trial. Prev. Med. (Baltim). 47, 537-43. https://doi.org/10.1016/j.ypmed.2008.06.018

Faggiano, F., Richardson, C., Bohrn, K., Galanti, M.R., 2007. A cluster randomized controlled trial of school-based prevention of tobacco, alcohol and drug use: the EU-Dap design and study population. Prev. Med. (Baltim). 44, 170-3. https://doi.org/10.1016/j.ypmed.2006.09.010

Faggiano, F., Vigna-Taglianti, F., Burkhart, G., Bohrn, K., Cuomo, L., Gregori, D., Panella, M., Scatigna, M., Siliquini, R., Varona, L., van der Kreeft, P., Vassara, M., Wiborg, G., Galanti, M.R., 2010. The effectiveness of a school-based substance abuse prevention program: 18-month follow-up of the EU-Dap cluster randomized controlled trial. Drug Alcohol Depend. 108, 56-64. https://doi.org/10.1016/j.drugalcdep.2009.11.018

Farhat, T., Iannotti, R.J., Simons-Morton, B.G., 2010. Overweight, obesity, youth, and health-risk behaviors. Am. J. Prev. Med. 38, 258-67. https://doi.org/10.1016/j.amepre.2009.10.038 
Foxcroft, D.R., Tsertsvadze, A., 2011. Universal school-based prevention programs for alcohol misuse in young people. Cochrane database Syst. Rev. CD009113.

https://doi.org/10.1002/14651858.CD009113

Freedman, D.S., Khan, L.K., Serdula, M.K., Dietz, W.H., Srinivasan, S.R., Berenson, G.S., 2005. The relation of childhood BMI to adult adiposity: the Bogalusa Heart Study. Pediatrics 115, 22-7. https://doi.org/10.1542/peds.2004-0220

Galanti, M.R., Siliquini, R., Cuomo, L., Melero, J.C., Panella, M., Faggiano, F., 2007. Testing anonymous link procedures for follow-up of adolescents in a school-based trial: the EU-DAP pilot study. Prev. Med. (Baltim). 44, 174-7. https://doi.org/10.1016/j.ypmed.2006.07.019

Goldstein, J.S., Little, S.G., Akin-Little, K.A., 2003. Absenteeism: A Review of the Literature and School Psychology's Role. Calif. Sch. Psychol. 8, 127-139. https://doi.org/10.1007/BF03340901

Gorini, G., Carreras, G., Bosi, S., Tamelli, M., Monti, C., Storani, S., Martini, A., Allara, E., Angelini, P., Faggiano, F., 2014. Effectiveness of a school-based multi-component smoking prevention intervention: The LdP cluster randomized controlled trial. Prev. Med. (Baltim). 61, 6-13. https://doi.org/10.1016/j.ypmed.2014.01.004

Italian National Institute of Statistics (ISTAT), 2017. Statistiche demografiche ISTAT.

Kahan, B.C., Jairath, V., Doré, C.J., Morris, T.P., 2014. The risks and rewards of covariate adjustment in randomized trials: an assessment of 12 outcomes from 8 studies. Trials 15, 139. https://doi.org/10.1186/1745-6215-15-139

Khaw, K.-T., Wareham, N., Bingham, S., Welch, A., Luben, R., Day, N., 2008. Combined impact of health behaviours and mortality in men and women: the EPIC-Norfolk prospective population study. PLoS Med. 5, e12. https://doi.org/10.1371/journal.pmed.0050012

Kvaavik, E., Batty, G.D., Ursin, G., Huxley, R., Gale, C.R., 2010. Influence of individual and combined health behaviors on total and cause-specific mortality in men and women: the United Kingdom health and lifestyle survey. Arch. Intern. Med. 170, 711-8.

https://doi.org/10.1001/archinternmed.2010.76

MacArthur, G.J., Smith, M.C., Melotti, R., Heron, J., Macleod, J., Hickman, M., Kipping, R.R., Campbell, R., Lewis, G., 2012. Patterns of alcohol use and multiple risk behaviour by gender during early and late adolescence: the ALSPAC cohort. J. Public Health (Oxf). 34 Suppl 1, i20-30. https://doi.org/10.1093/pubmed/fds006

Marshall, E.J., 2014. Adolescent alcohol use: risks and consequences. Alcohol Alcohol 49, 160-4. https://doi.org/10.1093/alcalc/agt180

McCambridge, J., McAlaney, J., Rowe, R., 2011. Adult consequences of late adolescent alcohol consumption: a systematic review of cohort studies. PLoS Med. 8, e1000413. https://doi.org/10.1371/journal.pmed.1000413

Nanchahal, K., Power, T., Holdsworth, E., Hession, M., Sorhaindo, A., Griffiths, U., Townsend, J., Thorogood, N., Haslam, D., Kessel, A., Ebrahim, S., Kenward, M., Haines, A., 2012. A pragmatic randomised controlled trial in primary care of the Camden Weight Loss (CAMWEL) programme. BMJ Open 2, e000793-e000793. https://doi.org/10.1136/bmjopen-2011-000793

Noar, S.M., Zimmerman, R.S., 2005. Health Behavior Theory and cumulative knowledge regarding 
health behaviors: are we moving in the right direction? Health Educ. Res. 20, 275-90. https://doi.org/10.1093/her/cyg113

Nunes, H.E.G., Gonçalves, E.C. de A., Vieira, J.A.J., Silva, D.A.S., 2016. Clustering of Risk Factors for Non-Communicable Diseases among Adolescents from Southern Brazil. PLoS One 11, e0159037. https://doi.org/10.1371/journal.pone.0159037

Roberts, C., Torgerson, D.J., 1999. Understanding controlled trials: Baseline imbalance in randomised controlled trials. BMJ 319, 185-185. https://doi.org/10.1136/bmj.319.7203.185

Royston, P., 2004. Multiple imputation of missing values. Stata J. 4, 227-241.

Rubin, D.B., 1976. Inference and Missing Data. Biometrika 63, 581. https://doi.org/10.2307/2335739

Schulz, K.F., Altman, D.G., Moher, D., 2010. CONSORT 2010 Statement: updated guidelines for reporting parallel group randomised trials. BMJ 340, c332-c332. https://doi.org/10.1136/bmj.c332

Silva, K.S. da, Lopes, A. da S., Vasques, D.G., Costa, F.F. da, Silva, R.C.R. da, 2012. Clustering of risk factors for chronic noncommunicable diseases among adolescents: prevalence and associated factors. Rev. Paul. Pediatr. 30, 338-345. https://doi.org/10.1590/S0103-05822012000300006

Sloboda, Z., Stephens, P., Pyakuryal, A., Teasdale, B., Stephens, R.C., Hawthorne, R.D., Marquette, J., Williams, J.E., 2009a. Implementation fidelity: the experience of the Adolescent Substance Abuse Prevention Study. Health Educ. Res. 24, 394-406. https://doi.org/10.1093/her/cyn035

Sloboda, Z., Stephens, R.C., Stephens, P.C., Grey, S.F., Teasdale, B., Hawthorne, R.D., Williams, J., Marquette, J.F., 2009b. The Adolescent Substance Abuse Prevention Study: A randomized field trial of a universal substance abuse prevention program. Drug Alcohol Depend. 102, 1-10. https://doi.org/10.1016/j.drugalcdep.2009.01.015

Strauss, R.S., 2000. Childhood obesity and self-esteem. Pediatrics 105, e15.

Swallen, K.C., Reither, E.N., Haas, S.A., Meier, A.M., 2005. Overweight, obesity, and health-related quality of life among adolescents: the National Longitudinal Study of Adolescent Health. Pediatrics 115, 340-7. https://doi.org/10.1542/peds.2004-0678

Thomas, R.E., Mclennan, J., Perera, R., 2013. Cochrane in context: School-based programmes for preventing smoking. Evidence-Based Child Heal. https://doi.org/10.1002/ebch.1938

Waters, E., de Silva-Sanigorski, A., Hall, B.J., Brown, T., Campbell, K.J., Gao, Y., Armstrong, R., Prosser, L., Summerbell, C.D., 2011. Interventions for preventing obesity in children. Cochrane database Syst. Rev. CD001871. https://doi.org/10.1002/14651858.CD001871.pub3

White, I.R., Horton, N.J., Carpenter, J., Pocock, S.J., 2011. Strategy for intention to treat analysis in randomised trials with missing outcome data. BMJ 342, d40. https://doi.org/10.1136/bmj.d40

White, I.R., Royston, P., Wood, A.M., 2011. Multiple imputation using chained equations: Issues and guidance for practice. Stat. Med. 30, 377-99. https://doi.org/10.1002/sim.4067

WHO, 2010. Global strategy on diet, physical activity and health. Geneva.

WHO Europe, 2006. Gaining Health The European Strategy for the Prevention and Control of Noncommunicable Diseases. Copenhagen, Denmark, Denmark. 
Figure 1. Study profile

\section{A. Middle schools}

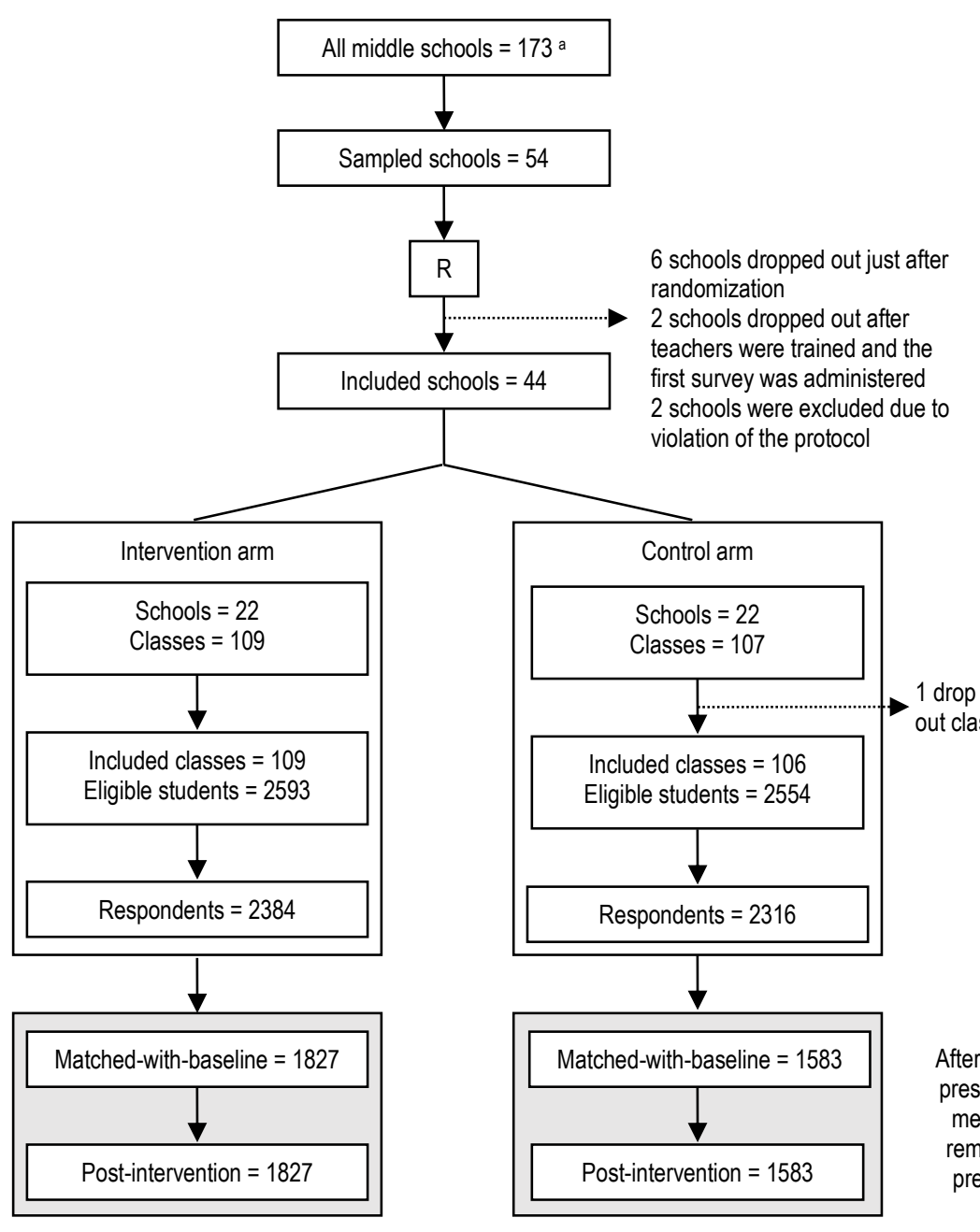

B. High schools

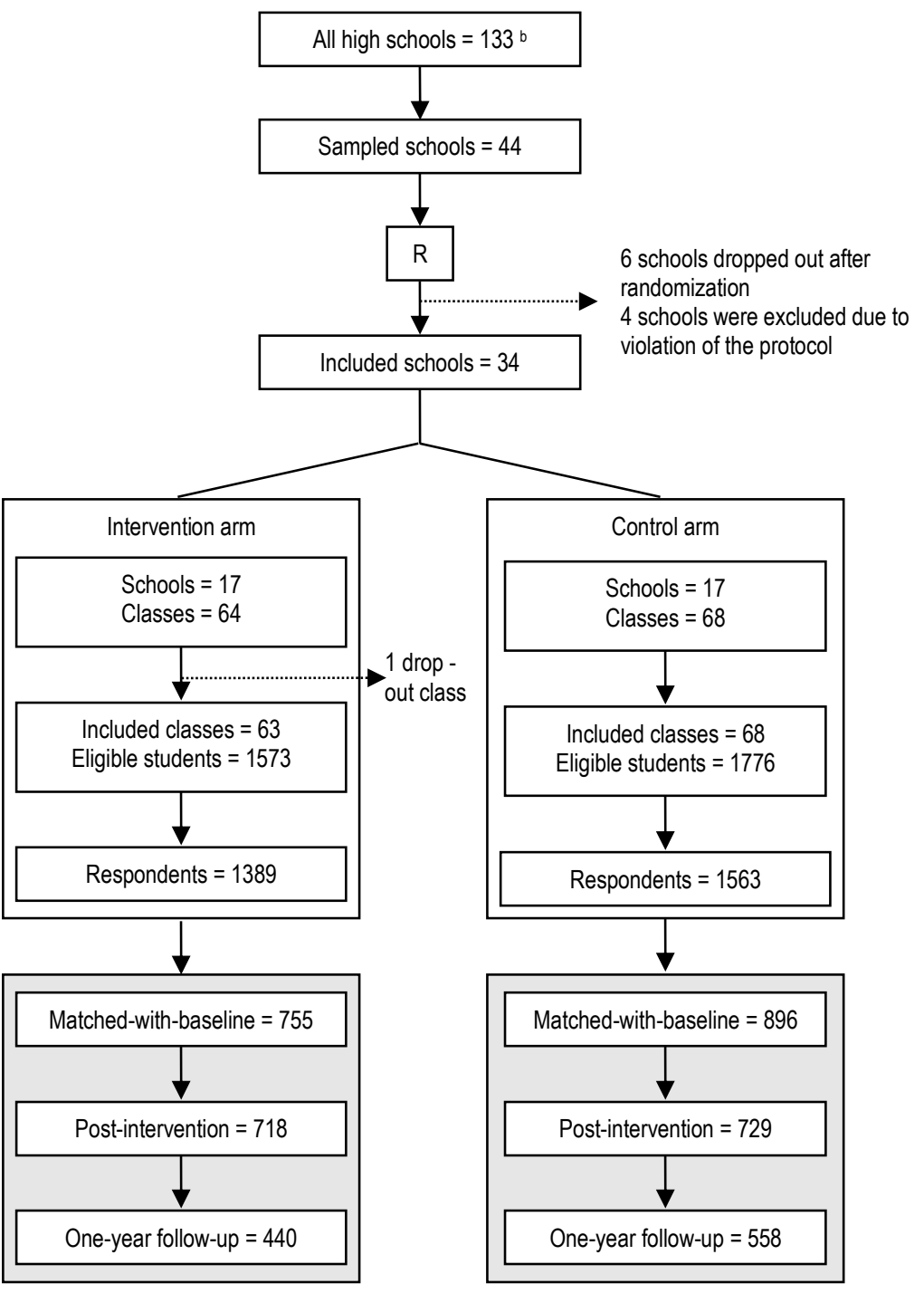

${ }^{a}$ From all administrative areas in the Italian region of Emilia-Romagna $\quad{ }^{b}$ From all administrative areas in the Italian region of Emilia-Romagna except for Reggio Emilia, already involved in another trial (Bosi et al., 2013; Gorini et al., 2014) 
Table 1. Adjusted program effects on cigarette smoking after multiple imputation of missing data
A. Middle schools

\begin{tabular}{|c|c|c|c|c|c|}
\hline & \multicolumn{2}{|c|}{ Baseline } & \multicolumn{3}{|c|}{ Post-intervention } \\
\hline & $\begin{array}{l}\text { Intervention } \\
\%(\mathrm{~N}=1827)\end{array}$ & $\begin{array}{c}\text { Control } \\
\%(\mathrm{~N}=1583)\end{array}$ & $\begin{array}{l}\text { Intervention } \\
\%(\mathrm{~N}=1827)\end{array}$ & $\begin{array}{c}\text { Control } \\
\%(\mathrm{~N}=1583)\end{array}$ & $\begin{array}{c}\text { AOR } \\
\text { OR (95\% CI) }\end{array}$ \\
\hline \multicolumn{6}{|c|}{ Past-30-day tobacco smoking: current (1+time) } \\
\hline Never & 92.6 & 91.7 & 92.6 & 92.7 & \multirow{3}{*}{$\begin{array}{c}1.06 \\
(0.73,1.55)\end{array}$} \\
\hline At least once & 1.4 & 1.3 & 5.3 & 5.2 & \\
\hline Missing & 6.1 & 7.0 & 2.1 & 2.1 & \\
\hline \multicolumn{6}{|l|}{ Past-30-day tobacco smoking: frequent $(20+)$} \\
\hline $0-19$ times & 93.8 & 92.8 & 96.6 & 96.7 & \multirow{3}{*}{$\begin{array}{c}1.51 \\
(0.57,3.96)\end{array}$} \\
\hline $20+$ times & 0.2 & 0.3 & 1.3 & 1.2 & \\
\hline Missing & 6.1 & 7.0 & 2.1 & 2.1 & \\
\hline
\end{tabular}

B. High schools

\begin{tabular}{|c|c|c|c|c|c|c|c|c|}
\hline & \multicolumn{2}{|c|}{ Baseline } & \multicolumn{3}{|c|}{ Post-intervention } & \multicolumn{3}{|c|}{ One-year follow-up } \\
\hline & $\begin{array}{c}\text { Intervention } \\
\%(\mathrm{~N}=755)\end{array}$ & $\begin{array}{c}\text { Control } \\
\%(\mathrm{~N}=896)\end{array}$ & $\begin{array}{c}\text { Intervention } \\
\%(\mathrm{~N}=755)\end{array}$ & $\begin{array}{c}\text { Control } \\
\%(\mathrm{~N}=896)\end{array}$ & $\begin{array}{c}\text { AOR } \\
(95 \% \mathrm{Cl})\end{array}$ & $\begin{array}{c}\text { Intervention } \\
\%(\mathrm{~N}=755)\end{array}$ & $\begin{array}{c}\text { Control } \\
\%(\mathrm{~N}=896)\end{array}$ & $\begin{array}{c}\text { AOR } \\
(95 \% \mathrm{Cl})\end{array}$ \\
\hline \multicolumn{9}{|c|}{ Past-30-day tobacco smoking: current (1+time) } \\
\hline Never & 76.7 & 80.6 & 54.0 & 54.8 & \multirow{3}{*}{$\begin{array}{c}0.97 \\
(0.71,1.32)\end{array}$} & 36.7 & 39.2 & \multirow{3}{*}{$\begin{array}{c}0.86 \\
(0.60,1.22)\end{array}$} \\
\hline $1+$ times & 17.3 & 13.8 & 25.0 & 24.1 & & 18.9 & 22.1 & \\
\hline Missing & 6.0 & 5.6 & 21.0 & 21.2 & & 44.4 & 38.8 & \\
\hline \multicolumn{9}{|c|}{ Past-30-day tobacco smoking: frequent $(20+)$} \\
\hline 0-19 times & 89.0 & 88.0 & 66.8 & 67.8 & \multirow{3}{*}{$\begin{array}{c}1.44 \\
(0.91,2.29)\end{array}$} & 44.7 & 50.4 & \multirow{3}{*}{$\begin{array}{c}1.34 \\
(0.93,1.94)\end{array}$} \\
\hline $20+$ times & 5.1 & 6.4 & 12.2 & 11.1 & & 10.9 & 10.9 & \\
\hline Missing & 6.0 & 5.6 & 21.0 & 21.2 & & 44.4 & 38.8 & \\
\hline
\end{tabular}

AOR, adjusted odds ratio of program effect accounting for behaviour at baseline, continuous age, sex, SES, origin, and (only for high-school students) attendance at vocational school

$\mathrm{Cl}$, confidence interval 
Table 2. Adjusted program effects on alcohol drinking after multiple imputation of missing data
A. Middle schools

\begin{tabular}{|c|c|c|c|c|c|}
\hline & \multicolumn{2}{|c|}{ Baseline } & \multicolumn{3}{|c|}{ Post-intervention } \\
\hline & $\begin{array}{c}\text { Intervention } \\
\%(\mathrm{~N}=1827)\end{array}$ & $\begin{array}{c}\text { Control } \\
\%(\mathrm{~N}=1583)\end{array}$ & $\begin{array}{c}\text { Intervention } \\
\%(\mathrm{~N}=1827)\end{array}$ & $\begin{array}{c}\text { Control } \\
\%(\mathrm{~N}=1583)\end{array}$ & $\begin{array}{c}\text { AOR } \\
(95 \% \mathrm{Cl})\end{array}$ \\
\hline \multicolumn{6}{|l|}{ Past-30-day alcohol misuse: current (1+) } \\
\hline Never & 92.2 & 91.4 & 95.4 & 94.4 & \multirow{3}{*}{$\begin{array}{c}0.82 \\
(0.47,1.42)\end{array}$} \\
\hline At least once & 1.5 & 1.4 & 2.6 & 3.4 & \\
\hline Missing data & 6.3 & 7.3 & 2.0 & 2.2 & \\
\hline \multicolumn{6}{|l|}{ Past-30-day alcohol misuse: frequent $(3+)$} \\
\hline $0-2$ times & 93.1 & 92.3 & 97.5 & 96.7 & \multirow{3}{*}{$\begin{array}{c}0.44 \\
(0.18,1.09)\end{array}$} \\
\hline $3+$ times & 0.6 & 0.4 & 0.5 & 1.1 & \\
\hline Missing data & 6.3 & 7.3 & 2.0 & 2.2 & \\
\hline
\end{tabular}

B. High schools

\begin{tabular}{|c|c|c|c|c|c|c|c|c|}
\hline & \multicolumn{2}{|c|}{ Baseline } & \multicolumn{3}{|c|}{ Post-intervention } & \multicolumn{3}{|c|}{ One-year follow-up } \\
\hline & $\begin{array}{c}\text { Intervention } \\
\%(\mathrm{~N}=755)\end{array}$ & $\begin{array}{c}\text { Control } \\
\%(\mathrm{~N}=896)\end{array}$ & $\begin{array}{c}\text { Intervention } \\
\%(\mathrm{~N}=755)\end{array}$ & $\begin{array}{c}\text { Control } \\
\%(\mathrm{~N}=896)\end{array}$ & $\begin{array}{c}\text { AOR } \\
(95 \% \mathrm{Cl})\end{array}$ & $\begin{array}{c}\text { Intervention } \\
\%(\mathrm{~N}=755)\end{array}$ & $\begin{array}{c}\text { Control } \\
\%(\mathrm{~N}=896)\end{array}$ & $\begin{array}{c}\text { AOR } \\
(95 \% \mathrm{Cl})\end{array}$ \\
\hline \multicolumn{9}{|c|}{ Past-30-day alcohol misuse: current (1+) } \\
\hline Never & 86.6 & 86.6 & 62.1 & 63.9 & 1.18 & 43.6 & 46.1 & \multirow{3}{*}{$\begin{array}{c}0.78 \\
(0.54,1.13)\end{array}$} \\
\hline $1+$ times & 7.3 & 7.1 & 16.6 & 14.9 & $(0.83$ & 11.4 & 15.1 & \\
\hline Missing & 6.1 & 6.4 & 21.3 & 21.2 & $1.68)$ & 45.0 & 38.8 & \\
\hline \multicolumn{9}{|c|}{ Past-30-day alcohol misuse: frequent $(3+)$} \\
\hline $0-2$ times & 91.5 & 91.6 & 74.9 & 74.0 & 0.79 & 52.3 & 57.5 & \multirow{3}{*}{$\begin{array}{c}0.81 \\
(0.45,1.49)\end{array}$} \\
\hline $3+$ times & 2.4 & 2.0 & 3.9 & 4.8 & $(0.47$ & 2.8 & 3.8 & \\
\hline Missing & 6.1 & 6.4 & 21.3 & 21.2 & $1.33)$ & 45.0 & 38.8 & \\
\hline
\end{tabular}

AOR, adjusted odds ratio of program effect accounting for behaviour at baseline, continuous age, sex, SES, origin, and (only for high-school students) attendance at vocational school

$\mathrm{Cl}$, confidence interval 
Table 3. Adjusted program effects on eating behaviour after multiple imputation of missing data
A. Middle schools

\begin{tabular}{|c|c|c|c|c|c|}
\hline & \multicolumn{2}{|c|}{ Baseline } & \multicolumn{3}{|c|}{ Post-intervention } \\
\hline & $\begin{array}{c}\text { Interventio } \\
n \\
\%(\mathrm{~N}=1827)\end{array}$ & $\begin{array}{c}\text { Control } \\
\%(\mathrm{~N}=1583)\end{array}$ & $\begin{array}{c}\text { Interventio } \\
n\end{array}$ & $\begin{array}{c}\begin{array}{c}\text { Control } \\
\% \\
(\mathrm{~N}=1583)\end{array} \\
\end{array}$ & $\begin{array}{c}\text { AOR } \\
(95 \% \mathrm{Cl})\end{array}$ \\
\hline \multicolumn{6}{|l|}{ Vegetables consumption every day } \\
\hline 0-6 times/week & 64.0 & 63.6 & 70.0 & 67.0 & 0.84 \\
\hline Every day & 34.9 & 35.4 & 29.4 & 32.9 & $(0.69$ \\
\hline Missing data & 1.0 & 1.0 & 0.7 & 0.2 & $1.02)$ \\
\hline \multicolumn{6}{|l|}{ Fruit consumption every day } \\
\hline 0-6 times/week & 59.1 & 57.7 & 66.2 & 62.4 & 0.82 \\
\hline Every day & 40.0 & 41.3 & 33.0 & 37.4 & $(0.68$ \\
\hline Missing data & 0.9 & 1.0 & 0.9 & 0.3 & $0.99)$ \\
\hline \multicolumn{6}{|l|}{ Breakfast every day } \\
\hline 0-6 times/week & 28.8 & 27.4 & 33.7 & 31.8 & 0.94 \\
\hline Every day & 70.8 & 72.2 & 66.1 & 67.7 & $(0.76$ \\
\hline Missing data & 0.4 & 0.4 & 0.2 & 0.5 & 1.16) \\
\hline \multicolumn{6}{|l|}{ Sugar-sweetened drinks $4+$ times/week } \\
\hline 0-3 times/week & 59.8 & 61.2 & 62.6 & 64.2 & 1.08 \\
\hline $4+$ times/week & 38.6 & 38.1 & 36.6 & 34.9 & $(0.90$ \\
\hline Missing data & 1.6 & 0.8 & 0.8 & 0.9 & $1.29)$ \\
\hline \multicolumn{6}{|l|}{ Crisps and snacks 4+ times/week } \\
\hline 0-3 times/week & 65.4 & 65.1 & 71.5 & 72.0 & 1.02 \\
\hline $4+$ times/week & 31.7 & 31.7 & 27.0 & 26.6 & $(0.85$ \\
\hline Missing data & 2.9 & 3.2 & 1.5 & 1.4 & $1.22)$ \\
\hline \multicolumn{6}{|l|}{ Cakes and ice creams 4+ times/week } \\
\hline 0-3 times/week & 62.2 & 61.7 & 63.4 & 60.8 & 0.90 \\
\hline 4+ times/week & 36.2 & 36.6 & 36.0 & 38.3 & $(0.76$ \\
\hline Missing data & 1.6 & 1.7 & 0.7 & 0.8 & $1.07)$ \\
\hline
\end{tabular}

B. High schools

\begin{tabular}{|c|c|c|c|c|c|c|c|c|}
\hline & \multicolumn{2}{|c|}{ Baseline } & \multicolumn{3}{|c|}{ Post-intervention } & \multicolumn{3}{|c|}{ One-year follow-up } \\
\hline & $\begin{array}{c}\text { Intervention } \\
\%(\mathrm{~N}=755)\end{array}$ & $\begin{array}{c}\text { Control } \\
\%(\mathrm{~N}=896)\end{array}$ & $\begin{array}{c}\text { Interventio } \\
n \\
\%(\mathrm{~N}=755)\end{array}$ & $\begin{array}{c}\text { Control } \\
\%(\mathrm{~N}=896)\end{array}$ & $\begin{array}{c}\text { AOR } \\
(95 \% \mathrm{Cl})\end{array}$ & $\begin{array}{c}\text { Interventio } \\
n \\
\%(\mathrm{~N}=755)\end{array}$ & $\begin{array}{c}\text { Control } \\
\%(N=896)\end{array}$ & $\begin{array}{c}\text { AOR } \\
(95 \% \mathrm{Cl})\end{array}$ \\
\hline \multicolumn{9}{|l|}{ Vegetables consumption every day } \\
\hline 0-6 times/week & 66.9 & 69.5 & 57.2 & 56.1 & 0.85 & 38.7 & 40.2 & 0.85 \\
\hline Every day & 32.2 & 29.6 & 24.5 & 25.1 & $(0.65$ & 19.4 & 22.4 & (0.61, \\
\hline Missing data & 0.9 & 0.9 & 18.4 & 18.8 & 1.11) & 41.9 & 37.4 & 1.19) \\
\hline \multicolumn{9}{|l|}{ Fruit consumption every day } \\
\hline 0-6 times/week & 62.6 & 66.4 & 54.1 & 55.2 & 0.95 & 39.5 & 41.2 & 0.88 \\
\hline Every day & 36.7 & 32.9 & 27.7 & 25.8 & $(0.74$ & 18.2 & 20.8 & $(0.63$ \\
\hline Missing data & 0.7 & 0.7 & 18.2 & 19.0 & $1.22)$ & 42.3 & 38.0 & 1.22) \\
\hline \multicolumn{9}{|l|}{ Breakfast every day } \\
\hline 0-6 times/week & 35.4 & 34.8 & 33.4 & 30.1 & 0.76 & 21.0 & 20.0 & 0.94 \\
\hline Every day & 64.2 & 64.8 & 48.5 & 51.4 & $(0.58$ & 37.1 & 42.6 & (0.69, \\
\hline Missing data & 0.4 & 0.3 & 18.1 & 18.5 & $0.99)$ & 41.9 & 37.4 & 1.28) \\
\hline \multicolumn{9}{|l|}{ Sugar-sweetened drinks 4+ times/week } \\
\hline 0-3 times/week & 55.1 & 55.5 & 52.8 & 50.1 & 0.92 & 40.2 & 45.6 & 1.11 \\
\hline $4+$ times/week & 43.5 & 43.6 & 28.9 & 31.0 & (0.70, & 17.7 & 16.8 & $(0.80$ \\
\hline Missing data & 1.5 & 0.9 & 18.4 & 18.9 & $1.22)$ & 42.2 & 37.6 & $1.55)$ \\
\hline \multicolumn{9}{|l|}{ Crisps and snacks 4+ times/week } \\
\hline 0-3 times/week & 61.7 & 63.7 & 57.7 & 57.3 & 1.06 & 43.4 & 48.6 & 1.09 \\
\hline $4+$ times/week & 36.7 & 34.6 & 23.7 & 23.2 & $(0.79$ & 14.4 & 13.4 & $(0.76$ \\
\hline Missing data & 1.6 & 1.7 & 18.6 & 19.5 & 1.42) & 42.3 & 38.0 & $1.54)$ \\
\hline \multicolumn{9}{|l|}{ Cakes and ice creams $4+$ times/week } \\
\hline 0-3 times/week & 57.7 & 59.0 & 48.1 & 47.7 & 0.95 & 35.8 & 41.2 & 1.16 \\
\hline 4+ times/week & 41.0 & 39.1 & 33.2 & 33.6 & $(0.75$ & 21.9 & 21.5 & $(0.87$ \\
\hline Missing data & 1.3 & 1.9 & 18.6 & 18.7 & 1.21) & 42.3 & 37.3 & 1.53) \\
\hline
\end{tabular}

AOR, adjusted odds ratio of program effect accounting for behaviour at baseline, continuous age, sex, SES, origin, and (only for high-school students) attendance at vocational school

$\mathrm{Cl}$, confidence interval 
Table 4. Adjusted program effects on physical activity and sedentary behaviour after multiple imputation of missing data

\section{A. Middle schools}

\begin{tabular}{|c|c|c|c|c|c|}
\hline & \multicolumn{2}{|c|}{ Baseline } & \multicolumn{3}{|c|}{ Post-intervention } \\
\hline & $\begin{array}{l}\text { Interventio } \\
n \\
\%(N=1827)\end{array}$ & $\begin{array}{c}\text { Control } \\
\%(\mathrm{~N}=1583)\end{array}$ & $\begin{array}{l}\text { Intervention } \\
\%(\mathrm{~N}=1827)\end{array}$ & $\begin{array}{c}\text { Control } \\
\%(\mathrm{~N}=1583)\end{array}$ & $\begin{array}{c}\text { AOR } \\
(95 \% \mathrm{Cl})\end{array}$ \\
\hline \multicolumn{6}{|l|}{ At least one hour of physical activity every day } \\
\hline $\begin{array}{r}0-6 \text { times/week } \\
\text { Every day } \\
\text { Missing data }\end{array}$ & $\begin{array}{l}84.2 \\
12.7 \\
3.1\end{array}$ & $\begin{array}{l}82.3 \\
14.0 \\
3.7\end{array}$ & $\begin{array}{l}81.3 \\
17.1 \\
1.5\end{array}$ & $\begin{array}{l}78.8 \\
19.0 \\
2.2\end{array}$ & $\begin{array}{c}0.92 \\
(0.75,1.13)\end{array}$ \\
\hline \multicolumn{6}{|l|}{ Intense ${ }^{a}$ physical activity every day } \\
\hline $\begin{array}{r}0-6 \text { times/week } \\
\text { Every day } \\
\text { Missing data }\end{array}$ & $\begin{array}{l}92.5 \\
6.0 \\
1.5\end{array}$ & $\begin{array}{l}91.3 \\
7.3 \\
1.5\end{array}$ & $\begin{array}{l}92.4 \\
6.8 \\
0.8\end{array}$ & $\begin{array}{l}89.9 \\
9.2 \\
1.0\end{array}$ & $\begin{array}{c}0.76 \\
(0.56,1.02)\end{array}$ \\
\hline \multicolumn{6}{|l|}{ Watches TV $3+$ hours every day } \\
\hline $\begin{array}{r}0-2 \text { hours/day } \\
3+\text { hours/day }\end{array}$ & $\begin{array}{l}68.1 \\
30.9\end{array}$ & $\begin{array}{l}70.3 \\
28.9\end{array}$ & $\begin{array}{l}71.7 \\
27.6\end{array}$ & $\begin{array}{l}70.3 \\
29.1\end{array}$ & \multirow[t]{2}{*}{$\begin{array}{c}0.90 \\
(0.73,1.10)\end{array}$} \\
\hline Missing data & 0.9 & 0.8 & 0.7 & 0.6 & \\
\hline \multicolumn{6}{|l|}{ Uses computer or videogames $3+$ hours/day } \\
\hline $0-2$ hours/day & 72.9 & 72.8 & 67.4 & 65.6 & \multirow{3}{*}{$\begin{array}{c}0.93 \\
(0.78,1.12)\end{array}$} \\
\hline $3+$ hours/day & 25.8 & 26.3 & 32.1 & 33.7 & \\
\hline Missing data & 1.3 & 0.9 & 0.4 & 0.8 & \\
\hline
\end{tabular}

B. High schools

\begin{tabular}{|c|c|c|c|c|c|c|c|c|}
\hline & \multicolumn{2}{|c|}{ Baseline } & \multicolumn{3}{|c|}{ Post-intervention } & \multicolumn{3}{|c|}{ One-year follow-up } \\
\hline & $\begin{array}{c}\text { Intervention } \\
\%(\mathrm{~N}=755)\end{array}$ & $\begin{array}{c}\text { Control } \\
\%(\mathrm{~N}=896)\end{array}$ & $\begin{array}{c}\text { Intervention } \\
\%(\mathrm{~N}=755)\end{array}$ & $\begin{array}{c}\text { Control } \\
\%(\mathrm{~N}=896)\end{array}$ & $\begin{array}{c}\text { AOR } \\
(95 \% \mathrm{Cl})\end{array}$ & $\begin{array}{c}\text { Intervention } \\
\%(\mathrm{~N}=755)\end{array}$ & $\begin{array}{c}\text { Control } \\
\%(\mathrm{~N}=896)\end{array}$ & $\begin{array}{c}\text { AOR } \\
(95 \% \mathrm{Cl})\end{array}$ \\
\hline \multicolumn{9}{|c|}{ At least one hour of physical activity every day } \\
\hline 0-6 times/week & 85.9 & 83.1 & 71.0 & 68.2 & 0.90 & 48.7 & 52.9 & 0.97 \\
\hline Every day & 12.4 & 15.0 & 10.4 & 12.0 & $(0.65$ & 7.7 & 9.2 & (0.66, \\
\hline Missing data & 1.7 & 1.9 & 18.6 & 19.8 & 1.25) & 43.6 & 38.0 & 1.44) \\
\hline \multicolumn{9}{|l|}{ Intense ${ }^{a}$ physical activity every day } \\
\hline $0-6$ times/week & 94.2 & 91.5 & 76.3 & 76.0 & 1.16 & 55.1 & 58.5 & 0.81 \\
\hline Every day & 4.9 & 7.1 & 5.2 & 5.3 & $(0.74$ & 3.1 & 4.1 & $(0.46$ \\
\hline Missing data & 0.9 & 1.5 & 18.5 & 18.7 & 1.81) & 41.9 & 37.4 & 1.43) \\
\hline \multicolumn{9}{|l|}{ Watches TV $3+$ hours every day } \\
\hline $0-2$ hours/day & 69.2 & 67.1 & 61.0 & 57.0 & 0.85 & 45.5 & 48.0 & 0.81 \\
\hline $3+$ hours/day & 29.7 & 32.0 & 21.0 & 24.2 & $(0.64$ & 12.2 & 14.5 & $(0.57$ \\
\hline Missing data & 1.2 & 0.9 & 18.0 & 18.8 & 1.14) & 42.3 & 37.5 & $1.16)$ \\
\hline \multicolumn{9}{|c|}{ Uses computer or videogames $3+$ hours/day } \\
\hline $0-2$ hours/day & 63.8 & 60.7 & 53.7 & 48.6 & 0.85 & 42.7 & 46.0 & 1.07 \\
\hline $3+$ hours/day & 35.4 & 38.8 & 28.3 & 32.1 & $(0.64$ & 14.9 & 16.6 & $(0.78$ \\
\hline Missing data & 0.8 & 0.6 & 18.0 & 19.3 & 1.11) & 42.4 & 37.4 & $1.46)$ \\
\hline
\end{tabular}

a Defined as 'any activity that results in increased heart rate and breathlessness some if the time for at least 60 minutes' (Adams et al., 2013) AOR, adjusted odds ratio of program effect accounting for behaviour at baseline, continuous age, sex, SES, origin, and (only for high-school students) attendance at vocational school

$\mathrm{Cl}$, confidence interval 


\section{Appendix A. Measures and test-retest correlations}

The outcomes evaluated in this trial originate from 12 measures available from the Italian version of the Health Behaviour in School-aged Children questionnaire (Cavallo et al., 2016), and presented in the table below. Questions about smoking and alcohol misuse were phrased as: 'and 'How many times did you get drunk (if you did) in the past 30 days', and students had to choose one of the following responses: 0 times, 1-2 times, 3-5 times, 6-9 times, 10-19 times, 20-29 times, 30 or more times. For eating behaviour and physical activity, we asked the weekly frequency of each behaviour, and enabled selection of one of the following responses: ' 0 times, 1-3 times, 4-5 times, more than 5 times, every day at least once'. In regard to sedentary behaviour, the question was phrased as 'Usually, in your spare time, how many hours per day do you spend...' with the relevant behaviour described after this, and students could choose one of the following responses: 0 hours, 1-2 hours, 3-4 hours, more than 4 hours.

A test-retest investigation was carried out on the same measures as part of a different study (Allara et al., 2018). Given the pertinence of these results for the 'Paesaggi di Prevenzione' trial, we decided to add a summary of the test-retest study in regard to the specific measures used in this trial. Briefly, the test-retest investigation was conducted in 2013 in the Italian region of Piedmont, which was not involved in the 'Paesaggi di Prevenzione' trial and has sociodemographic characteristics that are broadly similar to those of the Emilia-Romagna region where the trial was conducted (Italian National Institute of Statistics (ISTAT), 2017). Three classes were involved. Seventy-two students filled out the questionnaire at baseline and 68 after one month. Fourty-nine students completed both questionnaires and were included in the analysis sample. Their demographic characteristics (mean age 12 years, 53\% boys) overlap with those of middle school students included in the 'Paesaggi di Prevenzione' trial at baseline (mean age 12 years, $51 \%$ boys).

Six outcomes had Pearson's correlation coefficient greater than or equal to 0.70 , indicating strong or very strong correlation, three between 0.40 and 0.70 , reflecing moderate correlation, and five lower than 0.4 , suggesting low correlation. Overall, test-rest analysis highlights acceptable reliability for the measures used in this trial, although low correlation was noted in a minority of measures.

\begin{tabular}{|l|c|}
\hline Measure & Test-retest Pearson correlation \\
\hline Past-30-day tobacco smoking & $0.9481^{* *}$ \\
\hline Past-30-day alcohol misuse & $-0,0361$ \\
\hline Vegetables consumption every day & $0.7298^{* *}$ \\
\hline Fruit consumption every day & $0.7011^{* *}$ \\
\hline Breakfast every day & $0.7840^{* *}$ \\
\hline Sugar-sweetened drinks 4+ times/week & $0.7166^{* *}$ \\
\hline Crisps and snacks 4+ times/week & 0.3552 \\
\hline Cakes and ice creams 4+ times/week & 0.3584 \\
\hline At least one hour of physical activity every day & $0.6074^{*}$ \\
\hline Intense physical activity every day & 0.3787 \\
\hline Watches TV 3+ hours every day & $0.4445^{*}$ \\
\hline Uses computer or videogames 3+ hours/day & $0.5721^{*}$ \\
\hline
\end{tabular}

* Moderate correlation $(0.40 \leq$ Pearson's $r<0.70)$

** Strong or very strong correlation (Pearson's $r \geq 0.70$ ) 


\section{Appendix B. Full results of complete-case and multiple-imputation analyses}

\section{A. Middle schools}

\begin{tabular}{|c|c|c|c|c|}
\hline \multirow[b]{2}{*}{ Variabile } & \multicolumn{2}{|c|}{ Post-intervention (CCA) } & \multicolumn{2}{|c|}{ Post-intervention (MI) } \\
\hline & $\begin{array}{c}\text { Model } 1 \\
\text { OR }(95 \% \mathrm{Cl})\end{array}$ & $\begin{array}{c}\text { Model } 2 \\
\text { OR }(95 \% \mathrm{Cl})\end{array}$ & $\begin{array}{c}\text { Model } 1 \\
\text { OR }(95 \% \mathrm{Cl})\end{array}$ & $\begin{array}{c}\text { Model } 2 \\
\text { OR }(95 \% \mathrm{Cl})\end{array}$ \\
\hline Past-30-day tobacco smoking: current (1+time) & $1.01(0.67 .1 .51)$ & $1.01(0.69,1.48)$ & $1.03(0.69,1.53)$ & $1.06(0.73,1.55)$ \\
\hline Past-30-day tobacco smoking: frequent $(20+)$ & $1.17(0.53,2.58)$ & $1.05(0.46,2.39)$ & $1.40(0.56,3.48)$ & $1.51(0.57,3.96)$ \\
\hline Past-30-day alcohol misuse: current $(1+)$ & $0.82(0.49,1.37)$ & $0.84(0.49,1.45)$ & $0.79(0.45,1.36)$ & $0.82(0.47,1.42)$ \\
\hline Past-30-day alcohol misuse: frequent $(3+)$ & $0.44(0.19,0.99)$ & $0.45(0.19,1.07)$ & $0.42(0.18,0.99)$ & $0.44(0.18,1.09)$ \\
\hline Vegetables consumption every day & $0.84(0.69,1.03)$ & $0.84(0.68,1.03)$ & $0.85(0.69,1.04)$ & $0.84(0.69,1.02)$ \\
\hline Fruit consumption every day & $0.82(0.67,1.01)$ & $0.83(0.68,1.00)$ & $0.83 \S(0.68,1.00)$ & $0.82(0.68,0.99)$ \\
\hline Breakfast every day & $0.95(0.76,1.18)$ & $0.96(0.78,1.20)$ & $0.94(0.76,1.17)$ & $0.94(0.76,1.16)$ \\
\hline Sugar-sweetened drinks $4+$ times/week & $1.06(0.86,1.31)$ & $1.07(0.87,1.31)$ & $1.06(0.89,1.27)$ & $1.08(0.90,1.29)$ \\
\hline Crisps and snacks $4+$ times/week & $0.97(0.79,1.21)$ & $0.99(0.81,1.20)$ & $1.01(0.85,1.20)$ & $1.02(0.85,1.22)$ \\
\hline Cakes and ice creams $4+$ times/week & $0.91(0.76,1.08)$ & $0.92(0.77,1.11)$ & $0.90(0.76,1.07)$ & $0.90(0.76,1.07)$ \\
\hline At least one hour of physical activity every day & $0.90(0.74,1.10)$ & $0.98(0.79,1.22)$ & $0.90(0.73,1.10)$ & $0.92(0.75,1.13)$ \\
\hline Intense $e^{a}$ physical activity every day & $0.74(0.56,0.98)$ & $0.73(0.55,0.98)$ & $0.73(0.54,0.99)$ & $0.76(0.56,1.02)$ \\
\hline Watches TV $3+$ hours every day & $0.89(0.71,1.10)$ & $0.90(0.71,1.14)$ & $0.88(0.72,1.08)$ & $0.90(0.73,1.10)$ \\
\hline Uses computer or videogames $3+$ hours/day & $0.94(0.77,1.15)$ & $0.96(0.79,1.16)$ & $0.93(0.77,1.12)$ & $0.93(0.78,1.12)$ \\
\hline
\end{tabular}

\section{B. High schools}

\begin{tabular}{|c|c|c|c|c|c|c|c|c|}
\hline \multirow[b]{2}{*}{ Variabile } & \multicolumn{2}{|c|}{ Post-intervention (CCA) } & \multicolumn{2}{|c|}{ One-year follow-up (CCA) } & \multicolumn{2}{|c|}{ Post-intervention (MI) } & \multicolumn{2}{|c|}{ One-year follow-up (MI) } \\
\hline & $\begin{array}{c}\text { Model } 1 \\
\text { OR (95\% Cl) }\end{array}$ & $\begin{array}{c}\text { Model } 2 \\
\text { OR }(95 \% \mathrm{Cl})\end{array}$ & $\begin{array}{c}\text { Model } 1 \\
\text { OR (95\% Cl) }\end{array}$ & $\begin{array}{c}\text { Model } 2 \\
\text { OR }(95 \% \mathrm{Cl})\end{array}$ & $\begin{array}{c}\text { Model } 1 \\
\text { OR (95\% Cl) }\end{array}$ & $\begin{array}{c}\text { Model } 2 \\
\text { OR }(95 \% \mathrm{Cl})\end{array}$ & $\begin{array}{c}\text { Model } 1 \\
\text { OR (95\% Cl) }\end{array}$ & $\begin{array}{c}\text { Model } 2 \\
\text { OR }(95 \% \text { Cl) }\end{array}$ \\
\hline Past-30-day tobacco smoking: current (1+time) & $0.96(0.67,1.38)$ & $1.09(0.76,1.55)$ & $0.83(0.58,1.19)$ & $0.90(0.62,1.31)$ & $0.92(0.67,1.28)$ & $0.97(0.71,1.32)$ & $0.85(0.60,1.21)$ & $0.86(0.60,1.22)$ \\
\hline Past-30-day tobacco smoking: frequent $(20+)$ & $1.34(0.79,2.27)$ & $1.44(0.83,2.49)$ & $1.35(0.89,2.06)$ & $1.45(0.94,2.26)$ & $1.36(0.84,2.19)$ & $1.44(0.91,2.29)$ & $1.30(0.89,1.90)$ & $1.34(0.93,1.94)$ \\
\hline Past-30-day alcohol misuse: current (1+) & $1.17(0.78,1.74)$ & $1.21(0.80,1.85)$ & $0.77(0.49,1.21)$ & $0.80(0.51,1.25)$ & $1.16(0.81,1.66)$ & $1.18(0.83,1.68)$ & $0.76(0.53,1.10)$ & $0.78(0.54,1.13)$ \\
\hline Past-30-day alcohol misuse: fre & $0.80(0.47,1.35)$ & $0.83(0.48,1.43)$ & $0.79(0.39,1.58)$ & $0.80(0.42,1.54)$ & $0.79(0.47,1.32)$ & $0.79(0.47,1.33)$ & $0.75(0.38,1.49)$ & $0.81(0.45,1.49)$ \\
\hline Vegetables consumption every day & $0.88(0.67,1$. & $0.83(0.63,1.10)$ & $0.85(0.59,1.22)$ & $9(0.58,1.07)$ & $37(0.66,1.15)$ & $0.85(0.65,1.11)$ & $0.92(0.6$ & \\
\hline Fruit consumption every day & $1.04(0.75,1.44)$ & $0.93(0.72,1.21)$ & $0.88(0.57,1.35)$ & $0.88(0.61,1.26)$ & $1.02(0.74,1.40)$ & $0.95(0.74,1.22)$ & $0.92(0.61,1.38)$ & $0.88(0.63,1.22)$ \\
\hline Breakfast every day & $0.81(0.58,1.13)$ & $0.80(0.60,1.07)$ & $0.85(0.63,1.14)$ & $0.88(0.64,1.20)$ & $0.78(0.56,1.09)$ & $0.76(0.58,0.99)$ & $0.95(0.68,1.31)$ & $0.94(0.69,1.28)$ \\
\hline Sugar-sweetened drinks $4+$ times/week & $0.82(0.56,1.19)$ & $0.88(0.65,1.19)$ & $1.09(0.73,1.64)$ & $1.18(0.85,1.65)$ & $0.87(0.61,1.25)$ & $0.92(0.70,1.22)$ & $1.01(0.67,1.53)$ & $1.11(0.80,1.55)$ \\
\hline Crisps and snacks $4+$ times/week & $1.02(0.69,1.52)$ & $1.04(0.77,1.41)$ & $1.04(0.68,1.62)$ & $1.12(0.74,1.69)$ & $1.04(0.71,1.54)$ & $1.06(0.79,1.42)$ & $1.03(0.68,1.54)$ & $1.09(0.76,1.54)$ \\
\hline Cakes and ice creams $4+$ times/week & $0.97(0.75,1.25)$ & $0.95(0.74,1.22)$ & $1.12(0.84,1.49)$ & $1.14(0.86,1.52)$ & $0.94(0.74,1.20)$ & $0.95(0.75,1.21)$ & $1.12(0.84,1.49)$ & $1.16(0.87,1.53)$ \\
\hline At least one hour of physical activity every day & $0.85(0.61,1.18)$ & $0.91(0.65,1.29)$ & $0.97(0.64,1.47)$ & $1.04(0.69,1.57)$ & $0.86(0.63,1.19)$ & $0.90(0.65,1.25)$ & $0.94(0.64,1.38)$ & $0.97(0.66,1.44)$ \\
\hline Intensea physical activity every day & $1.10(0.70,1.73)$ & $1.23(0.77,1.96)$ & $0.85(0.49,1.48)$ & $0.94(0.53,1.66)$ & $1.08(0.70,1.67)$ & $1.16(0.74,1.81)$ & $0.78(0.44,1.38)$ & $0.81(0.46,1.43)$ \\
\hline Watches TV $3+$ hours every day & $0.81(0.57,1.14)$ & $0.83(0.61,1.12)$ & $0.83(0.52,1.35)$ & $0.79(0.53,1.18)$ & $0.81(0.58,1.14)$ & $0.85(0.64,1.14)$ & $0.77(0.48,1.23)$ & $0.81(0.57,1.16)$ \\
\hline Uses computer or videogames $3+$ hours/day & $0.78(0.56,1.11)$ & $0.80(0.61,1.05)$ & $1.00(0.71,1.41)$ & $0.95(0.70,1.29)$ & $0.80(0.57,1.13)$ & $0.85(0.64,1.11)$ & $1.02(0.69,1.51)$ & $1.07(0.78,1.46)$ \\
\hline
\end{tabular}

a Defined as 'any activity that results in increased heart rate and breathlessness some if the time for at least 60 minutes' (Adams et al., 2013)
CCA, complete-case analysis
Ml, multiple imputation
OR, odds ratio
$\mathrm{Cl}$, confidence interval

Model 1: program effect program adjusted for behaviour at baseline

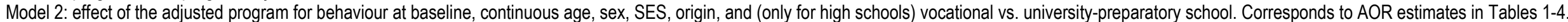

